\title{
Examining the Influence of COVID 19 Pandemic in Changing Customers' Orientation towards E-Shopping
}

\author{
Dr. Tareq N. Hashem ${ }^{1}$ \\ ${ }^{1}$ Associate professor, Head of Marketing Department, Isra University, Amman, Jordan \\ Correspondence: Dr. Tareq N. Hashem, Associate professor, Head of Marketing Department, Isra University, \\ Amman, Jordan.
}

Received: June 22, 2020

Accepted: July 10, 2020

Online Published: July 14, 2020

doi:10.5539/mas.v14n8p59

URL: https://doi.org/10.5539/mas.v14n8p59

\begin{abstract}
Current study aimed at examining the change in customer behavior during COVID 19 pandemic towards e-shopping. Variables taken into perspective included (Frequency, Necessity, Method of Payment, Price, and Availability of Product/Service). A simple random sample of (500) citizens in Jordan were exposed to an online questionnaire regarding their consuming behavior before and after the pandemic. Results of study indicated the COVID19 pandemic managed to change customer behavior towards depending more on online shopping and e-payment methods during COVID19 pandemic and the circumstances of lockdown and quarantine, in addition to that, results of pre and post behavior indicated that the influence appeared to be more influenced by gender and academic qualification as females' behavior appeared to be more influential and those who held a diploma. Study recommended that companies need to develop effective marketing strategies and enhance their presence in the e-commerce sector.
\end{abstract}

However, one question remained unanswered; will society's behavior change after the pandemic's demise, and will this behavior turn into an economic mind that measures things in numbers?

Keywords: e-shopping, pandemic, customer behavior, intention, payment-method, online payment

\section{Introduction}

Each society has its own culture and civilization, and this culture is formed over hundreds of years, and its personality is formed in comparison to other societies (Pandža Bajs, 2015). According to Kumar et al (2016), the culture and civilization of society is the set of prevailing values, customs, traditions and beliefs, and civilization consists of two elements, one of which is abstract or moral, and is represented in the fundamental values of society, its customs, traditions and beliefs, and the other element is material it is the material product of the members of society, and the continuous interaction between society and the individual leads to the formation of the individual's purchasing and consumer preferences in a way that is compatible with the fundamental values of society, and accordingly the types of products that society is allowed to be purchased and consumed are determined, and these fundamental values of society enjoy the obligation where no individual can deviate from them (Jaakkola and Alexander, 2014). For example, there are some societies whose civilization allows them to eat dog meat and pigs, as some societies allow to eat fish meat alive or to eat frogs, and these behaviors are unacceptable in other societies, especially Islamic societies because their intrinsic values do not recognize this and do not allow it. Based on that, Shah et al (2014) noted that the purchase behavior of individuals is bound to the values and traditions of their societies and do not contradict them, as a result, it can be said that the values of society, its beliefs, customs and traditions in the general behavior of its members constitute their purchasing behavior.

According to Wang (2015), the flow of information regarding a certain change in the environment influences the consumer behavior in a massive way, on the other hand Voinea and Filip (2011) noted that the frequency and availability of goods/services can influence the way a customer behaves; when a certain items item is scarce and not available; customers tend to hoard this item to avoid the trouble of looking for it. Czarniewski (2014) also suggested that some aspects can change customers' behavior like prices and methods of payment; customers tend to adopt a new behavior as soon as they find the financial methods are suitable for them. 
From that point, current study seeks to examine the influence of COVID 19 pandemic and the quarantine situation in changing customers' behavior to e-shopping and using electronic approaches to purchase items. Variable used in current study depended on drivers of customer behavior change including (Frequency, Necessity, Method of Payment, Price, and Availability of Product/Service).

Following model represented the relationship that gathered the variables together:

Independent Variable

Dependent rariable

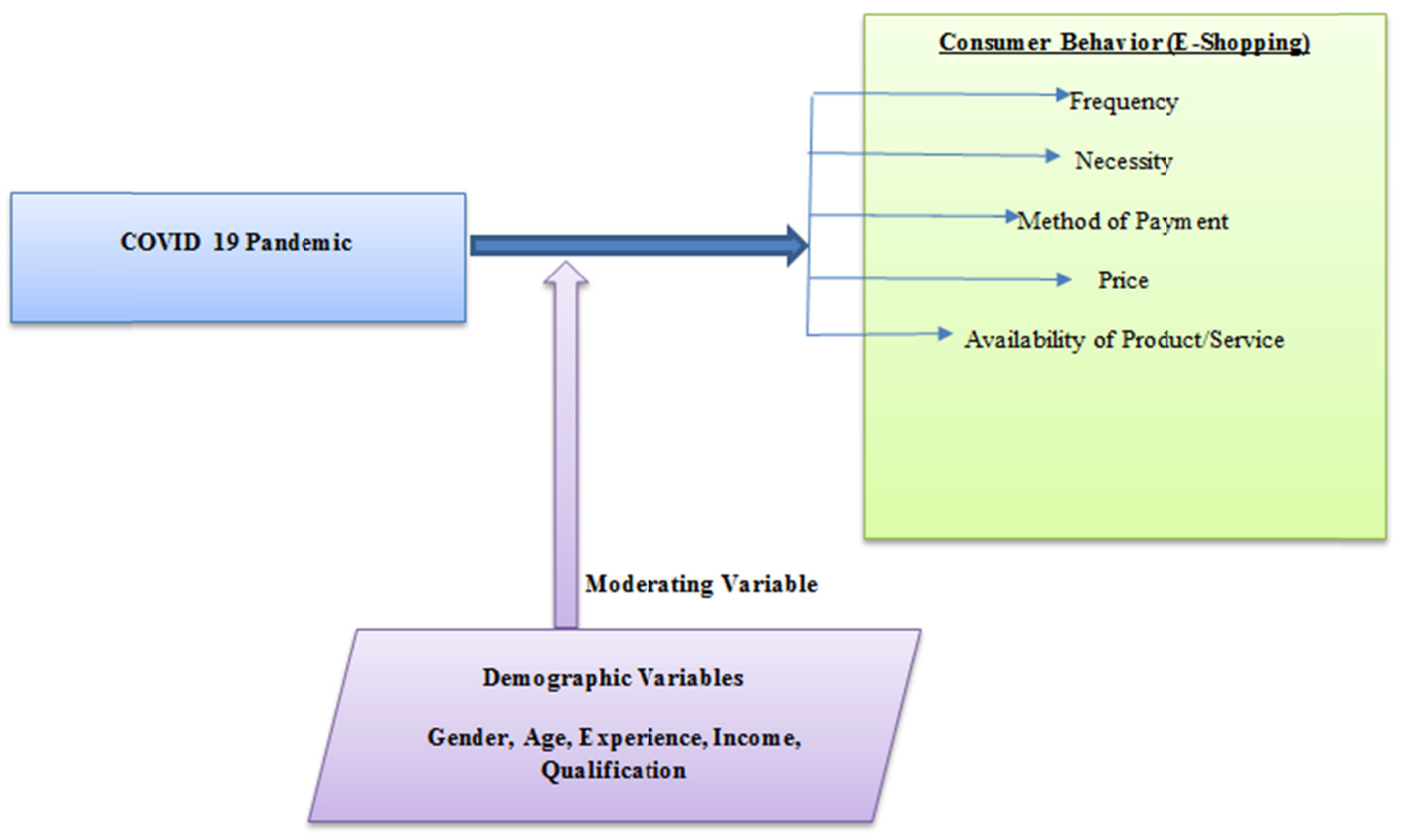

Figure 1. Study Model

From above model, following hypotheses were extracted:

H1: COVID 19 had an influence over customer behavior through increasing the tendency towards e-shopping

H2: Attitudes toward over Customer behavior (e-shopping) after the appearance of COVID19 are not changed due to demographics of individuals

From that point, current study hypothesize that due to the limited movement among individuals that was restricted during the overall lockdown in Jordan due to VOCID19 virus; customer behavior changed dramatically and their interest, intention and behavior leaned more towards the use of e-shopping methods through multiple websites and online platforms which were built on the bases of online payment.

\section{Literature Review}

\subsection{Customer Behavior}

Behavior is generally defined as the way in which living organisms deal and act with environmental conditions through an activity whose purpose is to modify or change these conditions, so that they are appropriate to them and their requirements in order to be able to live and survive (Han et al, 2015).

Before referring to the definition of consumer behavior, the concept of 'consumer' must be defined first, Kannan et al (2015) defined consumer/ customer as "a person who buys or has the ability to purchase goods and services offered for sale, with the aim of satisfying personal or family needs and desires, Juaneda-Ayensa et al (2016) noted that a customer is divided into two types, the first type is a person/ individual who purchases goods that they need for their personal or family use, while the other type is the industrial customer which includes all 
private and public organizations that search for products and purchase them for use in achieving their goals and future plans.

It is understood from this definition that every person is considered a consumer/customer, so that the primary motivation for them is to satisfy their needs and desires according to what is available in the market on one hand, and according to their financial and cognitive capabilities and purchasing abilities on the other hand ( $\mathrm{Yu}$ et al, 2017).

\subsection{Definition of Customer Behavior}

As for consumer behavior, scholars presented many definitions that helped to give overall definitions for the concept, among them Echchakoui (2016) who stated that consumer's behavior is defined as the behavior that the consumer highlights in the search for buying or using goods, services and ideas, which he expects will satisfy his desires or needs according to his available purchasing capabilities, also, Moon et al (2015) saw that customer behavior is all direct and indirect actions and behaviors that consumers perform in order to obtain a good or service in a specific place and at a specific time. From another perspective Singh and Singh (2015) defined customer behavior as the set of mental and muscular activities related to the evaluation and differentiation process, and obtaining goods, services, ideas, and how to use them.

\subsection{Constituents of Customer Behavior}

Constituents of customers' behavior is usually influenced and infused by the culture and society that people live in Jung and Yoo (2017), this managed the culture to have a deep impact on how consumers behave in reference to purchase behaviors and intentions. Juaneda-Ayensa et al (2016) argued that customer behavior might be bound to many factors that shapes its final frame, among these factors are the external environmental factors for the consumer; such factors include the external environmental influences that affect the consumer, which are civilizational and cultural influences, social influences, situational influences and marketing influences. Echchakoui (2016) saw that society culture determines the form and philosophy of consumption for its members through the values and beliefs that forms it. For example, the philosophy of consumption in Western societies focuses on material well-being and aims to maximize recreational consumption in the world, while consumer philosophy in Islamic societies reduces the over-exploitation of material enjoyment and requires the individual to maintain a balance between the material and the spiritual side of their life.

Sweeney et al (2015) argued that Islamic culture, for example, prohibits the consumption of or trade in some foodstuffs, such as blood, pork, and wines, as the Hindu culture prohibits the slaughter and eating of cows, Consumers buy products according to the culture of their societies, for reasons including:

- Consumers believe that the purchased good or service will do its best job.

- Buying the commodity for its shape, form and image.

- Buying a commodity for its symbolic meaning, such as the association of some foods with the religious and national occasions of society.

- The influence of social classes on consumer behavior.

Others scholars saw that constituents of customer behavior is something that can't be defined easily, sometimes customer behavior is influenced by other factors than society including desires, needs, motives, cognitive skills, learning abilities, awareness, and many other factors that in overall would help in defining what constitute the behavior of customers Zhang and Benyoucef (2016); De Mooij (2019); Claiborne and Sirgy (2015); and Sudbury-Riley and Kohlbacher (2016).

\subsection{The Shift towards E-Payment Methods}

Mathras et al (2015) emphasized that there is a clear change on the shopping habits of individuals, which became clear more during the past years with the spread of smart and Internet-based mobile devices in all their features, which led to the explosion of electronic commerce and the high level of electronic payment by individuals. Previously, shopping in a store and paying in cash was a common method of commerce that today, shopping through the Internet and relying on electronic payment cards has become a distinctive feature of this era in a way that is - and radically - the behavior of consumers around the world.

One of the important drivers that contributed to the spread of the concept of payment through the Internet was coupled with electronic commerce, which has evolved and has become opportunities for consumers to obtain their needs without the need to move from one place to another and therefore only content with sitting at home and requesting services, goods and goods until Threshold of their house through electronic payment and the use of various bank payment cards (Dakduk et al, 2017). 
This tendency towards relying on electronic payment has become an advantage of development and openness, and avoiding cash payment, as there is no need for direct dealing with currencies as long as there is an approved electronic payment method that meets the purpose, and this was in the normal state of countries (Tankovic and Benazic, 2018). Although the World Health Organization confirmed that the emerging coronavirus is transmitted through coughing and sneezing spray, it stressed the ability to transmit it across surfaces and paper currencies which created a huge boost among individuals to deeply embrace e-shopping and e-payments methods as an approach to get all they need from goods and services with the privilege of not using paper money and expose themselves to the dangers of getting infected by the virus (Lin et al, 2018).

\section{Hypotheses Building}

\subsection{Frequency}

It is evident from the various reports that sales in the markets of consumer goods and products (food commodities, beverages, refreshments, cosmetics, cleaning materials, etc.) have increased remarkably since the beginning of the year 2020 to mid-century due to the quarantine conditions that accompanied the pandemic, which forced many individuals to rush to the markets Because of the complete closures that various countries have exercised over their sectors (Lim, 2015). Calder et al (2016) stated that in the stage of partial openness, individuals have always avoided mixing and leaving by purchasing their most necessary supplies and relying on electronic payment methods without using regular money. So, this explains the changes in customer behavior during the pandemic to the decrease in the frequency of shopping and attributed to the quarantine and lockdown that was imposed by the government in the country.

\subsection{Necessity}

Lantos (2015) confirms that consumer behavior is greatly affected by the environmental conditions surrounding it, both inside the home, that within the entire country, as the consumer usually tends during exceptional circumstances to change the consumption pattern towards necessities more than luxuries as a way to regulate expenses and not reach the stage of inability to Securing basic requirements (Campbell and Frei, 2010).

\section{Method of Payment}

Data pointed out that the fears and dismay of the Corona pandemic led to changes in consumption patterns, as the restrictions imposed on citizens in last April 2020 and obliged the conditions of movement and shopping in a limited geographical area have prompted them to buy their needs from the Internet using electronic payment methods such as cards Credit, PayPal, and so on, which led to an increase in the sales of many stores that offer online shopping services during the first five months of 2020 by a very high rate (Jiang and Chen, 2016). This indicates that the surrounding environmental conditions will affect the behavior of the consumer and push him to reach his needs and desires through electronic payment and shopping methods as long as the service is present and available by the banks that are dealing with it, thus developing the hypothesis that supports the fact that during the pandemic citizens became more dependent on payment methods that doesn't require them to move from one place to another.

\subsection{Price}

Zhang et al (2017) Indicates that changes in the internal environment of consumers, whether in terms of prices, supply and demand, forced many individuals to change consumption patterns that they have been accustomed to for decades because of the unprecedented price hikes that their markets may witness, especially food, whether produced locally or imported. Consequently, this change in the market and the rise in prices may cause individuals to gradually liberate themselves from consumption habits that no longer fit their income and price increases (Vazifedoost et al, 2013). Also, the significant decline that markets may experience as a result of higher living standards in addition to fixed wages may force individuals to change their consumption habits and purchasing patterns (Lu et al, 2010). Öğüt and Onur Taş (2012) added that the changing consumer behavior of citizens is important, even if there is no rise in prices, because this is in the interest of the consumer in terms of controlling its expenditures and not wasting supplies and contributing to controlling the market through moderate demand.

From that point, we can say that changes in Jordanian customer behavior during COVID 19 pandemic was influenced by the prices which made them to make purchase decisions through e-payment portals and methods. 


\subsection{Availability of Product/Service}

Steinhart et al (2013) argued that the availability of products and services plays a huge role in changing customer behavior. Authors argued that the availability of products online or through the website may trigger the purchase intention in a customer to make online purchase decisions that are supported by online payment methods.

\subsection{Methods}

Current study adopted quantitative approach in order to realize hypotheses presented before. A questionnaire was developed and appeared in two main sections; the first took into account demographics of study sample, while the other section of questionnaire consisted of statements related to variables of study in two main parts (Pre-COVID 19 and Post-COVID 19) in order to measure the difference of behavior during the two periods of times. Population of study consisted of all Jordanian consumers during the first half of 2020. A simple random sample of (580) individuals were exposed to the online version of the questionnaire which was uploaded on Google forms. After leaving the questionnaire for 7 weeks online, researcher found total of (500) questionnaires which were properly filled and ready to be exposed to statistical analysis with a response ratio of $86.2 \%$.

Cronbach alpha is used to test the reliability of the scale, it is found that alpha $=0.967$ reflects that the questionnaire is reliable since it is greater than accepted percent 0.60 (Sekaran \& Bougie, 2016).

\section{Analysis and Discussion}

\subsection{Demographics}

Table 1. Sample Characteristics According to Demographics

\begin{tabular}{|c|c|c|c|c|c|}
\hline \multicolumn{6}{|c|}{ Gender } \\
\hline & & Frequency & Percent & Valid Percent & Cumulative Percent \\
\hline \multirow[t]{3}{*}{ Valid } & Male & 263 & 52.6 & 52.6 & 52.6 \\
\hline & Female & 237 & 47.4 & 47.4 & 100.0 \\
\hline & Total & 500 & 100.0 & 100.0 & \\
\hline \multicolumn{6}{|c|}{ Age } \\
\hline & & Frequency & Percent & Valid Percent & Cumulative Percent \\
\hline \multirow[t]{5}{*}{ Valid } & $18-28$ & 58 & 11.6 & 11.6 & 11.6 \\
\hline & $29-39$ & 109 & 21.8 & 21.8 & 33.4 \\
\hline & $40-50$ & 158 & 31.6 & 31.6 & 65.0 \\
\hline & +51 & 175 & 35.0 & 35.0 & 100.0 \\
\hline & Total & 500 & 100.0 & 100.0 & \\
\hline \multicolumn{6}{|c|}{ Frequency of E-Shopping } \\
\hline & & Frequency & Percent & Valid Percent & Cumulative Percent \\
\hline \multirow[t]{5}{*}{ Valid } & Once/month & 30 & 6.0 & 6.0 & 6.0 \\
\hline & Twice/month & 83 & 16.6 & 16.6 & 22.6 \\
\hline & 3times/month & 147 & 29.4 & 29.4 & 52.0 \\
\hline & +4 times/month & 240 & 48.0 & 48.0 & 100.0 \\
\hline & Total & 500 & 100.0 & 100.0 & \\
\hline \multicolumn{6}{|c|}{ Income/\$ } \\
\hline & & Frequency & Percent & Valid Percent & Cumulative Percent \\
\hline \multirow[t]{5}{*}{ Valid } & -500 & 27 & 5.4 & 5.4 & 5.4 \\
\hline & $501-750$ & 77 & 15.4 & 15.4 & 20.8 \\
\hline & $751-1000$ & 181 & 36.2 & 36.2 & 57.0 \\
\hline & +1001 & 215 & 43.0 & 43.0 & 100.0 \\
\hline & Total & 500 & 100.0 & 100.0 & \\
\hline
\end{tabular}




\begin{tabular}{cccccc}
\hline & & \multicolumn{5}{c}{ Education } \\
& & Frequency & Percent & Valid Percent & Cumulative Percent \\
\hline Valid & HighSchool & 21 & 4.2 & 4.2 & 4.2 \\
& Diploma & 127 & 25.4 & 25.4 & 29.6 \\
BA & 198 & 39.6 & 39.6 & 69.2 \\
& Higher & 154 & 30.8 & 30.8 & 100.0 \\
Studies & & & & \\
Total & 500 & 100.0 & 100.0 & \\
\hline
\end{tabular}

Table 1 above showed mean and standard deviation of sample characteristics according to demographics; it appeared through analysis that majority of sample responded to the questionnaire was males forming $52.6 \%$ of total sample with frequency 263 individuals which can be attributed to the fact that usually within the Jordanian culture it is the man who takes care of the household needs and necessities. On the other hand, and looking at the age of respondents, it appeared that majority of sample $51 \%$ were older than 51 years old compared to individuals within the age range of $18-28$ years old forming $11.6 \%$ of total sample.

When respondents were asked regarding the frequency of their behavior in depending on e-shopping to get their needs; results of study showed that $48 \%$ was the majority of sample respondents who depended on e-shopping to get their needs more than 4 times a month, this indicated that the culture of e-shopping and e-payment methods are known and accepted among the Jordanian culture. This was explained when results indicated that $43 \%$ of respondents had an income of more than $\$ 1001$ compared to those who had an income of less than $\$ 500$ forming $6.4 \%$ of total sample. As for education, it was seen that majority of sample responded to the questionnaire $39.6 \%$ had an MA degree compared to those who had a diploma forming $4.2 \%$ of total sample.

\subsection{Questionnaire Analysis}

Table 2. Descriptive Statistics of Customer Behavior Pre-COVID19

\begin{tabular}{|c|c|c|c|c|c|c|}
\hline & & $N$ & Minimum & Maximum & Mean & Std. Deviation \\
\hline \multicolumn{7}{|c|}{ Consumer Behavior (E-Shopping) } \\
\hline \multicolumn{7}{|c|}{ Pre-COVID19 } \\
\hline \multicolumn{7}{|c|}{ Frequency } \\
\hline I usually go shopping twice a month & .1 & 500 & 1 & 5 & 3.96 & 1.294 \\
\hline $\begin{array}{l}\text { I tend to use coupons within stores } \\
\text { that accepts it }\end{array}$ & .2 & 500 & 1 & 5 & 3.81 & 1.407 \\
\hline $\begin{array}{l}\text { I go shopping every time I find myself } \\
\text { free }\end{array}$ & f .3 & 500 & 1 & 5 & 3.61 & 1.582 \\
\hline $\begin{array}{c}\text { My shopping behaviors are all } \\
\text { organized and dated }\end{array}$ & .4 & 500 & 1 & 5 & 4.18 & 1.260 \\
\hline $\begin{array}{l}\text { My shopping frequency changes } \\
\text { according to my situation }\end{array}$ & .5 & 500 & 1 & 5 & 4.17 & 1.255 \\
\hline \multicolumn{7}{|c|}{ Necessity } \\
\hline $\begin{array}{l}\text { Unless it's food or medicine then it is } \\
\text { not necessary }\end{array}$ & .6 & 500 & 1 & 5 & 4.21 & 1.249 \\
\hline $\begin{array}{c}\text { Would buy complementary items if on } \\
\text { discount }\end{array}$ & .7 & 500 & 1 & 5 & 3.69 & 1.373 \\
\hline $\begin{array}{l}\text { I go shopping to have fun and enjoy } \\
\text { friends' company }\end{array}$ & .8 & 500 & 1 & 5 & 3.71 & 1.416 \\
\hline $\begin{array}{l}\text { I tend to try new items that I don't } \\
\text { need }\end{array}$ & .9 & 500 & 1 & 5 & 3.70 & 1.315 \\
\hline $\begin{array}{c}\text { I follow all my expenses on monthly } \\
\text { bases }\end{array}$ & .10 & 500 & 1 & 5 & 3.76 & 1.283 \\
\hline
\end{tabular}




\begin{tabular}{|c|c|c|c|c|c|}
\hline \multicolumn{6}{|c|}{ Method of Payment } \\
\hline I only pay in cash .11 & 500 & 1 & 5 & 4.16 & 1.025 \\
\hline I am a user-friendly of card payments .12 & 500 & 1 & 5 & 3.64 & 1.417 \\
\hline $\begin{array}{l}\text { My card supports e-shopping and I } .13 \\
\text { don't intend to visit my bank to } \\
\text { promote it }\end{array}$ & 500 & 1 & 5 & 3.65 & 1.419 \\
\hline I trust online payment methods .14 & 500 & 1 & 5 & 4.02 & 1.198 \\
\hline Scam is a big pet peeve for me .15 & 500 & 1 & 5 & 3.81 & 1.341 \\
\hline \multicolumn{6}{|c|}{ Price } \\
\hline $\begin{array}{l}\text { I compare item prices between } .16 \\
\text { different stores }\end{array}$ & 500 & 2 & 5 & 4.13 & 1.023 \\
\hline $\begin{array}{l}\text { I don't buy unnecessary items unless } \\
\text { it's on discount }\end{array}$ & 500 & 1 & 5 & 4.06 & 1.068 \\
\hline $\begin{array}{l}\text { I chose local products as they're less } .18 \\
\text { expensive than imported ones }\end{array}$ & 500 & 1 & 5 & 4.11 & 1.107 \\
\hline $\begin{array}{l}\text { I am willing to pay extra for food and } .19 \\
\text { medicine }\end{array}$ & 500 & 1 & 5 & 3.85 & 1.222 \\
\hline $\begin{array}{l}\text { I'm not willing to buy items that prices } .20 \\
\text { changed over time, I look for } \\
\text { alternatives }\end{array}$ & 500 & 1 & 5 & 3.94 & 1.154 \\
\hline \multicolumn{6}{|c|}{ Availability of Product/Service } \\
\hline I usually look for an item online .21 & 500 & 1 & 5 & 3.94 & 1.108 \\
\hline $\begin{array}{l}\text { If the item isn't available in stores and } .22 \\
\text { don't look for it on websites }\end{array}$ & 500 & 1 & 5 & 3.74 & 1.256 \\
\hline $\begin{array}{l}\text { If the item appeared to be necessary I } .23 \\
\text { would look for it online }\end{array}$ & 500 & 1 & 5 & 3.93 & 1.467 \\
\hline $\begin{array}{l}\text { I don't buy items online unless its } .24 \\
\text { cash on delivery }\end{array}$ & 500 & 1 & 5 & 4.22 & 1.386 \\
\hline $\begin{array}{c}\text { If the items isn't available in the } .25 \\
\text { market }\end{array}$ & 500 & 1 & 5 & 4.21 & 1.286 \\
\hline Valid N (listwise) & 500 & & & & \\
\hline
\end{tabular}

Above table 2 presented mean and standard deviation of questionnaire statements as according to respondents' answers to Consumer Behavior (E-Shopping) Pre-COVID19 ; it was seen through analysis that all respondents had a positive attitude towards statements of questionnaire considering that all statements scored higher than mean of scale 3.00 and was seen to be statistically positive.

As in the following table 3, it was also seen that respondents' attitude towards Consumer Behavior (E-Shopping) Pre-COVID19 appeared to be also positive given that all variables chosen in current study scored higher than mean of scale 3.00 which is statistically a positive result.

Table 3. Descriptive Statistics

\begin{tabular}{cccccc}
\hline & $N$ & Minimum & Maximum & Mean & Std. Deviation \\
\hline Frequency_pre-COVID19 & 500 & 1.00 & 5.00 & 3.9460 & 1.01746 \\
Necessity_pre-COVID19 & 500 & 1.60 & 5.00 & 3.8152 & 1.04324 \\
Method of Payment_pre-_COVID19 & 500 & 1.40 & 5.00 & 3.8572 & 1.10143 \\
Price_pre-_COVID19 & 500 & 1.20 & 5.00 & 4.0172 & 1.01022 \\
Availability of product/service_pre & 500 & 1.00 & 5.00 & 4.0072 & .94783 \\
COVID19 & & & & & \\
Pre-COVID19 & 500 & 1.80 & 5.00 & 3.9286 & .86130 \\
Valid N (listwise) & 500 & & & & \\
\hline
\end{tabular}


Table 4. Descriptive Statistics

\begin{tabular}{|c|c|c|c|c|c|c|}
\hline \multicolumn{7}{|c|}{$\begin{array}{c}\text { Consumer Behavior (E-Shopping) } \\
\text { Post-COVID19 } \\
\text { Frequency }\end{array}$} \\
\hline I usually go shopping twice a month & .26 & 500 & 1 & 5 & 4.59 & .942 \\
\hline $\begin{array}{l}\text { I tend to use coupons within stores } \\
\text { that accepts it }\end{array}$ & & 500 & 1 & 5 & 4.58 & .898 \\
\hline $\begin{array}{c}\text { I go shopping every time I find } .2 \\
\text { myself free }\end{array}$ & & 500 & 1 & 5 & 4.54 & .889 \\
\hline $\begin{array}{c}\text { My shopping behaviors are all } .2 \\
\text { organized and dated }\end{array}$ & & 500 & 1 & 5 & 4.32 & 1.084 \\
\hline $\begin{array}{c}\text { My shopping frequency changes } \\
\text { according to my situation }\end{array}$ & 30 & 500 & 1 & 5 & 4.56 & .910 \\
\hline \multicolumn{7}{|c|}{ Necessity } \\
\hline $\begin{array}{l}\text { Unless it's food or medicine then it is } \\
\text { not necessary }\end{array}$ & & 500 & 1 & 5 & 3.98 & 1.144 \\
\hline $\begin{array}{l}\text { Would buy complementary items if } \\
\text { on discount }\end{array}$ & .32 & 500 & 1 & 5 & 3.97 & 1.098 \\
\hline $\begin{array}{l}\text { I go shopping to have fun and enjoy } \\
\text { friends' company }\end{array}$ & .33 & 500 & 1 & 5 & 3.92 & 1.138 \\
\hline $\begin{array}{l}\text { I tend to try new items that I don't } \\
\text { need }\end{array}$ & .34 & 500 & 1 & 5 & 4.37 & 1.019 \\
\hline $\begin{array}{l}\text { I follow all my expenses on monthly } \\
\text { bases }\end{array}$ & .35 & 500 & 1 & 5 & 4.68 & .734 \\
\hline \multicolumn{7}{|c|}{ Method of Payment } \\
\hline I only pay in cash .36 & & 500 & 1 & 5 & 4.50 & .896 \\
\hline I am a user-friendly of card payments & s .37 & 500 & 1 & 5 & 4.59 & .942 \\
\hline $\begin{array}{c}\text { My card supports e-shopping and I } \\
\text { don't intend to visit my bank to } \\
\text { promote it }\end{array}$ & & 500 & 1 & 5 & 4.58 & .898 \\
\hline I trust online payment methods & & 500 & 1 & 5 & 4.54 & 889 \\
\hline Scam is a big pet peeve for me .4 & & 500 & 1 & 5 & 4.32 & 1.084 \\
\hline \multicolumn{7}{|c|}{ Price } \\
\hline $\begin{array}{c}\text { I compare item prices between } .4 \\
\text { different stores }\end{array}$ & 41 & 500 & 1 & 5 & 4.56 & .910 \\
\hline $\begin{array}{l}\text { I don't buy unnecessary items unless } \\
\text { it's on discount }\end{array}$ & .42 & 500 & 1 & 5 & 3.98 & 1.144 \\
\hline
\end{tabular}


I chose local products as they're less .43

500

1

5

3.97

1.098

expensive than imported ones

I am willing to pay extra for food and .44

500

1

5

3.92

medicine

I'm not willing to buy items that .45

500

1

5

4.37

1.019

prices changed over time

Availability of Product/Service

I usually look for an item online .46

$\begin{array}{lllll}500 & 1 & 5 & 4.68 & .734 \\ 500 & 1 & 5 & 4.50 & .896 \\ 500 & 1 & 5 & 4.59 & .942 \\ 500 & 1 & 5 & 4.58 & .898 \\ 500 & 1 & & & \\ & & 5 & 4.54 & .889\end{array}$

If the items isn't available in the .50

500

1

market I look for an alternative

Valid N (listwise)

500

Above table 4 presented mean and standard deviation of questionnaire statements as according to respondents' answers to Consumer Behavior (E-Shopping) Post-COVID19; it was seen through analysis that all respondents had a positive attitude towards statements of questionnaire considering that all statements scored higher than mean of scale 3.00 and was seen to be statistically positive. However, in the following table 5, it was also seen that respondents' attitude towards Consumer Behavior (E-Shopping) Post-COVID19 appeared to be also positive given that all variables chosen in current study scored higher than mean of scale 3.00 which is statistically a positive result.

Table 5. Descriptive Statistics

\begin{tabular}{cccccc}
\hline & $N$ & Minimum & Maximum & Mean & Std. Deviation \\
\hline Frequency_post-COVID19 & 500 & 1.00 & 5.00 & 4.5172 & .83823 \\
Necessity_post_COVID19 & 500 & 2.20 & 5.00 & 4.1844 & .77744 \\
Method of Payment_post_COVID19 & 500 & 1.00 & 5.00 & 4.5052 & .85935 \\
Price_post - COVID19 & 500 & 2.00 & 5.00 & 4.1600 & .80569 \\
Availability of product/service_post_- & 500 & 1.00 & 5.00 & 4.5772 & .80919 \\
COVID19 & & & & & .72445 \\
post -COVID19 & 500 & 1.80 & 5.00 & 4.3888 & \\
Valid N (listwise) & 500 & & & & \\
\hline
\end{tabular}




\section{Hypotheses Testing}

Previously set hypotheses of study were tested, following tables showed results of testing the hypotheses in accordance with study questions.

H1: COVID 19 had an influence over customer behavior through increasing the tendency towards e-shopping

Table 6. Paired Samples Statistics

\begin{tabular}{cccccc}
\hline & & Mean & $N$ & Std. Deviation & Std. Error Mean \\
\hline Pair 1 & Frequency_post & 4.5172 & 500 & .83823 & .03749 \\
& Frequency_pre & 3.9460 & 500 & 1.01746 & .04550 \\
Pair 2 & Necessity_post & 4.1844 & 500 & .77744 & .03477 \\
& Necessity_pre & 3.8152 & 500 & 1.04324 & .04666 \\
Pair 3 & Payment_post & 4.5052 & 500 & .85935 & .03843 \\
& Payment_pre & 3.8572 & 500 & 1.10143 & .04926 \\
Pair 4 & Price_post & 4.1600 & 500 & .80569 & .03603 \\
& Price_pre & 4.0172 & 500 & 1.01022 & .04518 \\
Pair 5 & Availability_post & 4.5772 & 500 & .80919 & .03619 \\
& Availability_pre & 4.0072 & 500 & .94783 & .04239 \\
Pair 6 & post & 4.3888 & 500 & .72445 & .03240 \\
& pre & 3.9286 & 500 & .86130 & .03852 \\
\hline
\end{tabular}

Table 7. Paired Samples Test

\begin{tabular}{|c|c|c|c|c|c|c|c|c|c|}
\hline & \multicolumn{5}{|c|}{ Paired Differences } & \multirow[b]{5}{*}{$t$} & \multirow[b]{5}{*}{$d f$} & \multirow[b]{4}{*}{ Sig. } \\
\hline & & \multirow[b]{4}{*}{ Mean } & \multirow{4}{*}{$\begin{array}{c}\text { Std. } \\
\text { Deviation }\end{array}$} & \multirow{4}{*}{$\begin{array}{l}\text { Std. Error } \\
\text { Mean }\end{array}$} & \multirow{2}{*}{\multicolumn{2}{|c|}{$\begin{array}{l}95 \% \text { Confidence } \\
\text { Interval of the }\end{array}$}} & & & \\
\hline & & & & & & & & & \\
\hline & & & & & Diff & ince & & & \\
\hline & & & & & Lower & Upper & & & (2-tailed) \\
\hline Pair 1 & $\begin{array}{l}\text { Frequency_post - } \\
\text { Frequency_pre }\end{array}$ & .57120 & 1.13779 & .05088 & .47123 & .67117 & 11.226 & 499 & .000 \\
\hline Pair 2 & $\begin{array}{l}\text { Necessity_post - } \\
\text { Necessity_pre }\end{array}$ & .36920 & .69277 & .03098 & .30833 & .43007 & 11.917 & 499 & .000 \\
\hline Pair 3 & $\begin{array}{l}\text { Payment_post - } \\
\text { Payment_pre }\end{array}$ & .64800 & 1.20124 & .05372 & .54245 & .75355 & 12.062 & 499 & .000 \\
\hline Pair 4 & $\begin{array}{l}\text { Price_post - } \\
\text { Price_pre }\end{array}$ & .14280 & .61342 & .02743 & .08890 & .19670 & 5.205 & 499 & .000 \\
\hline Pair 5 & $\begin{array}{c}\text { Availability_post - } \\
\text { Availability_pre }\end{array}$ & .57000 & .89486 & .04002 & .49137 & .64863 & 14.243 & 499 & .000 \\
\hline Pair 6 & post - pre & .46024 & .73261 & .03276 & .39587 & .52461 & 14.047 & 499 & .000 \\
\hline
\end{tabular}

Paired sample $t$ test is used to test above hypothesis, above table shows that the mean for each variable in the Post-COVID19 scale is greater than the mean for each variable in the Pre-COVID19 scale. Also, $t$ value for each variable and the total variables is significant at 0.05 levels, that means:

- COVID 19 had a positive influence over customer behavior through increasing the tendency towards e-shopping

- COVID 19 had an influence over (Frequency) variable used as an indicator for customer behavior through increasing the tendency towards e-shopping

- COVID 19 had an influence over (Necessity) variable used as an indicator for customer behavior through increasing the tendency towards e-shopping 
- COVID 19 had an influence over (Method of Payment) variable used as an indicator for customer behavior through increasing the tendency towards e-shopping

- COVID 19 had an influence over (Price) variable used as an indicator for customer behavior through increasing the tendency towards e-shopping

- COVID 19 had an influence over (Availability of Product / Service) variable used as an indicator for customer behavior through increasing the tendency towards e-shopping

H2: Attitudes toward over Customer behavior (e-shopping) after the appearance of COVID19 are changed due to demographics of individuals

Table 8. Multivariate Tests $^{\mathrm{a}}$

\begin{tabular}{|c|c|c|c|c|c|c|}
\hline \multicolumn{2}{|r|}{ Effect } & \multirow{2}{*}{$\frac{\text { Value }}{.635}$} & \multirow{2}{*}{$\frac{F}{170.149^{\mathrm{b}}}$} & \multirow{2}{*}{$\frac{\text { Hypothesis } d f}{5.000}$} & \multirow{2}{*}{$\frac{\text { Error } d f}{490.000}$} & \multirow{2}{*}{$\begin{array}{l}\text { Sig. } \\
.000\end{array}$} \\
\hline Intercept & Pillai's Trace & & & & & \\
\hline & Wilks' Lambda & .365 & $170.149^{b}$ & 5.000 & 490.000 & .000 \\
\hline & Hotelling's Trace & 1.736 & $170.149^{b}$ & 5.000 & 490.000 & .000 \\
\hline & Roy's Largest Root & 1.736 & $170.149^{b}$ & 5.000 & 490.000 & .000 \\
\hline \multirow[t]{4}{*}{ Gender } & Pillai's Trace & .208 & $25.704^{\mathrm{b}}$ & 5.000 & 490.000 & .000 \\
\hline & Wilks' Lambda & .792 & $25.704^{\mathrm{b}}$ & 5.000 & 490.000 & .000 \\
\hline & Hotelling's Trace & .262 & $25.704^{\mathrm{b}}$ & 5.000 & 490.000 & .000 \\
\hline & Roy's Largest Root & .262 & $25.704^{\mathrm{b}}$ & 5.000 & 490.000 & .000 \\
\hline \multirow[t]{4}{*}{ Age } & Pillai's Trace & .026 & $2.572^{\mathrm{b}}$ & 5.000 & 490.000 & .026 \\
\hline & Wilks' Lambda & .974 & $2.572^{\mathrm{b}}$ & 5.000 & 490.000 & .026 \\
\hline & Hotelling's Trace & .026 & $2.572^{\mathrm{b}}$ & 5.000 & 490.000 & .026 \\
\hline & Roy's Largest Root & .026 & $2.572^{b}$ & 5.000 & 490.000 & .026 \\
\hline Frequency of & Pillai's Trace & .032 & $3.236^{\mathrm{b}}$ & 5.000 & 490.000 & .007 \\
\hline \multirow[t]{3}{*}{ E-Shopping } & Wilks' Lambda & .968 & $3.236^{\mathrm{b}}$ & 5.000 & 490.000 & .007 \\
\hline & Hotelling's Trace & .033 & $3.236^{\mathrm{b}}$ & 5.000 & 490.000 & .007 \\
\hline & Roy's Largest Root & .033 & $3.236^{\mathrm{b}}$ & 5.000 & 490.000 & .007 \\
\hline \multirow[t]{4}{*}{ income } & Pillai's Trace & .003 & $.301^{\mathrm{b}}$ & 5.000 & 490.000 & .912 \\
\hline & Wilks' Lambda & .997 & $.301^{\mathrm{b}}$ & 5.000 & 490.000 & .912 \\
\hline & Hotelling's Trace & .003 & $.301^{\mathrm{b}}$ & 5.000 & 490.000 & .912 \\
\hline & Roy's Largest Root & .003 & $.301^{\mathrm{b}}$ & 5.000 & 490.000 & .912 \\
\hline \multirow[t]{4}{*}{ Education } & Pillai's Trace & .036 & $3.684^{\mathrm{b}}$ & 5.000 & 490.000 & .003 \\
\hline & Wilks' Lambda & .964 & $3.684^{\mathrm{b}}$ & 5.000 & 490.000 & .003 \\
\hline & Hotelling's Trace & .038 & $3.684^{\mathrm{b}}$ & 5.000 & 490.000 & .003 \\
\hline & Roy's Largest Root & .038 & $3.684^{\mathrm{b}}$ & 5.000 & 490.000 & .003 \\
\hline
\end{tabular}


Table 9. Tests of Between-Subjects Effects

\begin{tabular}{|c|c|c|c|c|c|c|}
\hline \multicolumn{7}{|c|}{ Type III Sum of } \\
\hline Source & Dependent Variable & Squares & $d f$ & Mean Square & $F$ & Sig. \\
\hline \multirow[t]{6}{*}{ Corrected Model } & Frequency_post & $28.570^{\mathrm{a}}$ & 5 & 5.714 & 8.765 & .000 \\
\hline & Necessity_post & $55.874^{\mathrm{b}}$ & 5 & 11.175 & 22.466 & .000 \\
\hline & Payment_post & $27.725^{\mathrm{c}}$ & 5 & 5.545 & 8.038 & .000 \\
\hline & Price_post & $59.972^{\mathrm{d}}$ & 5 & 11.994 & 22.448 & .000 \\
\hline & Availability_post & $22.148^{\mathrm{e}}$ & 5 & 4.430 & 7.184 & .000 \\
\hline & post & $28.801^{\mathrm{f}}$ & 5 & 5.760 & 12.208 & .000 \\
\hline \multirow[t]{6}{*}{ Intercept } & Frequency_post & 386.637 & 1 & 386.637 & 593.086 & .000 \\
\hline & Necessity_post & 175.633 & 1 & 175.633 & 353.090 & .000 \\
\hline & Payment_post & 383.172 & 1 & 383.172 & 555.451 & .000 \\
\hline & Price_post & 182.882 & 1 & 182.882 & 342.278 & .000 \\
\hline & Availability_post & 399.346 & 1 & 399.346 & 647.676 & .000 \\
\hline & post & 295.823 & 1 & 295.823 & 626.966 & .000 \\
\hline \multirow[t]{6}{*}{ Gender } & Frequency_post & 3.957 & 1 & 3.957 & 6.070 & .014 \\
\hline & Necessity_post & 48.809 & 1 & 48.809 & 98.126 & .000 \\
\hline & Payment_post & 3.977 & 1 & 3.977 & 5.764 & .017 \\
\hline & Price_post & 49.541 & 1 & 49.541 & 92.719 & .000 \\
\hline & Availability_post & 1.698 & 1 & 1.698 & 2.754 & .098 \\
\hline & post & 14.917 & 1 & 14.917 & 31.615 & .000 \\
\hline \multirow[t]{6}{*}{ Age } & Frequency_post & 1.483 & 1 & 1.483 & 2.275 & .132 \\
\hline & Necessity_post & 1.375 & 1 & 1.375 & 2.764 & .097 \\
\hline & Payment_post & 1.713 & 1 & 1.713 & 2.483 & .116 \\
\hline & Price_post & 1.333 & 1 & 1.333 & 2.495 & .115 \\
\hline & Availability_post & .634 & 1 & .634 & 1.029 & .311 \\
\hline & post & 1.277 & 1 & 1.277 & 2.706 & .101 \\
\hline Frequency of & Frequency_post & 2.123 & 1 & 2.123 & 3.257 & .072 \\
\hline \multirow[t]{5}{*}{ E-Shopping } & Necessity_post & .614 & 1 & .614 & 1.235 & .267 \\
\hline & Payment_post & 1.677 & 1 & 1.677 & 2.431 & .120 \\
\hline & Price_post & .327 & 1 & .327 & .611 & .435 \\
\hline & Availability_post & 1.871 & 1 & 1.871 & 3.034 & .082 \\
\hline & post & .306 & 1 & .306 & .648 & .421 \\
\hline \multirow[t]{6}{*}{ income } & Frequency_post & .107 & 1 & .107 & .165 & .685 \\
\hline & Necessity_post & .012 & 1 & .012 & .025 & .876 \\
\hline & Payment_post & .022 & 1 & .022 & .031 & .859 \\
\hline & Price_post & .000 & 1 & .000 & .001 & .978 \\
\hline & Availability_post & .004 & 1 & .004 & .006 & .938 \\
\hline & post & .008 & 1 & .008 & .017 & .897 \\
\hline \multirow[t]{4}{*}{ Education } & Frequency_post & 2.382 & 1 & 2.382 & 3.654 & .057 \\
\hline & Necessity_post & 2.442 & 1 & 2.442 & 4.910 & .027 \\
\hline & Payment_post & 1.878 & 1 & 1.878 & 2.722 & .100 \\
\hline & Price_post & 3.988 & 1 & 3.988 & 7.464 & .007 \\
\hline
\end{tabular}




\begin{tabular}{|c|c|c|c|c|c|c|}
\hline & Availability_post & 1.366 & 1 & 1.366 & 2.216 & .137 \\
\hline & post & 2.336 & 1 & 2.336 & 4.951 & .027 \\
\hline \multirow[t]{6}{*}{ Error } & Frequency_post & 322.042 & 494 & .652 & & \\
\hline & Necessity_post & 245.724 & 494 & .497 & & \\
\hline & Payment_post & 340.781 & 494 & .690 & & \\
\hline & Price_post & 263.948 & 494 & .534 & & \\
\hline & Availability_post & 304.592 & 494 & .617 & & \\
\hline & post & 233.086 & 494 & .472 & & \\
\hline \multirow[t]{6}{*}{ Total } & Frequency_post & 10553.160 & 500 & & & \\
\hline & Necessity_post & 9056.200 & 500 & & & \\
\hline & Payment_post & 10516.920 & 500 & & & \\
\hline & Price_post & 8976.720 & 500 & & & \\
\hline & Availability_post & 10802.120 & 500 & & & \\
\hline & post & 9892.669 & 500 & & & \\
\hline \multirow[t]{6}{*}{ Corrected Total } & Frequency_post & 350.612 & 499 & & & \\
\hline & Necessity_post & 301.598 & 499 & & & \\
\hline & Payment_post & 368.506 & 499 & & & \\
\hline & Price_post & 323.920 & 499 & & & \\
\hline & Availability_post & 326.740 & 499 & & & \\
\hline & post & 261.886 & 499 & & & \\
\hline
\end{tabular}
a. $\mathrm{R}$ Squared $=.081($ Adjusted R Squared $=.072)$
b. R Squared $=.185$ (Adjusted R Squared $=.177)$
c. R Squared $=.075($ Adjusted R Squared $=.066)$
d. R Squared $=.185$ (Adjusted R Squared $=.177)$
e. R Squared $=.068($ Adjusted R Squared $=.058)$
f. $\mathrm{R}$ Squared $=.110($ Adjusted R Squared $=.101)$

MANOVA test is used to test above hypothesis; it is found that Wilks' Lambda value is significant for (Gender, Age, Frequency of E-Shopping and Qualification) variables (except the income variable) at 0.05 levels. That means attitudes toward over Customer behavior (e-shopping) after the appearance of COVID19 are changed due to demographics of individuals (Gender, Age, Frequency of E-Shopping and Qualification).

Also it is found that:

- There are statistical differences in the attitudes toward (Frequency, Necessity, Payment, Price) variables due to gender and these differences tend to increase toward females more than males as shown in the following table: 
Table 10. Comparison Attributed to Gender

\begin{tabular}{ccccccc}
\hline & Gender & Frequency_post & Necessity_post & Payment_post & Price_post & post \\
\hline males & Mean & 4.4053 & 3.8776 & 4.3954 & 3.8456 & 4.2041 \\
& $\mathrm{~N}$ & 263 & 263 & 263 & 263 & 263 \\
& Std. Deviation & .85559 & .74919 & .89219 & .78850 & .71433 \\
females & Mean & 4.6414 & 4.5249 & 4.6270 & 4.5089 & 4.5938 \\
& $\mathrm{~N}$ & 237 & 237 & 237 & 237 & 237 \\
& Std. Deviation & .80221 & .65840 & .80588 & .67079 & .68044 \\
Total & Mean & 4.5172 & 4.1844 & 4.5052 & 4.1600 & 4.3888 \\
& $\mathrm{~N}$ & 500 & 500 & 500 & 500 & 500 \\
& Std. Deviation & .83823 & .77744 & .85935 & .80569 & .72445 \\
\hline
\end{tabular}

- There are statistical differences in the attitudes toward (Necessity and Price) variables due to Qualification and these differences tend to increase toward those who are holding diploma more than others, as shown in the following table:

Table 11. Comparison Attributed to Education

\begin{tabular}{ccccc}
\hline & Education & Necessity_post & Price_post & post \\
\hline High school & Mean & 3.6381 & 3.6857 & 4.2648 \\
& $\mathrm{~N}$ & 21 & 21 & 21 \\
& Std. Deviation & .38791 & .33806 & .23680 \\
diploma & Mean & 4.5890 & 4.5701 & 4.7480 \\
& $\mathrm{~N}$ & 127 & 127 & 127 \\
& Std. Deviation & .72256 & .75048 & .47493 \\
BA & Mean & 4.0909 & 4.0919 & 4.2608 \\
& $\mathrm{~N}$ & 198 & 198 & 198 \\
High Studies & .80242 & .81374 & .82320 \\
& Std. Deviation & 4.0455 & 3.9740 & 4.2740 \\
& Mean & 154 & 154 & 154 \\
Total & $\mathrm{N}$ & .69640 & .75795 & .70877 \\
& Std. Deviation & 4.1844 & 4.1600 & 4.3888 \\
& Mean & 500 & 500 & 500 \\
& N & .77744 & .80569 & .72445 \\
\hline
\end{tabular}

\section{Discussion}

Examining the above tables; it was seen that both hypotheses of study were accepted and there appeared to be an influence of COVID19 pandemic on customer behavior towards adopting e-shopping. In examining results of testing the first hypothesis "H1: COVID 19 had an influence over customer behavior through increasing the tendency towards e-shopping" the following were asserted:

- COVID 19 had a positive influence over customer behavior along with its adopted variables (Frequency, Necessity, Method of Payment, Price, and Availability of Product/Service) through increasing the tendency towards e-shopping

In other words; results of study indicated that online shopping using a website or application has become an increasingly important base for many consumers in the country, interest in e-shopping for grocery and other basic needs reached its peak in April, before it receded during May, which was expected given the circumstances of the lockdown in many country especially Jordan which has chosen the option of total lockdown for all sectors except healthcare sector which were adopted to accept infected individuals in special medical circumstances.

As for the $2^{\text {nd }}$ hypothesis of study articulated "H2: Attitudes toward Customer behavior (e-shopping) after the appearance of COVID19 are changed due to demographics of individuals"; results also supported the fact that 
demographics played a role in asserting the change of customer behavior attributed to COVID19 pandemic. Results indicated that the change of customer behavior during the pandemic was attributed to demographic variables manly gender in which females appeared to be more influence and those who had a diploma in terms of educational level as a demographic variable.

Based on what was mentioned above, study questions were answered and the pandemic of COVID19 played a role in changing customer behavior towards accepting e-shopping and depending on it as a daily life choice. This can be explained as individuals live in a set of circumstances specially designed for new behaviors that they need in their emergency position after the Corona pandemic, so when the right time comes and the days return to their former times, they feels as if they was born again, the isolation may be lengthened or shortened, and it can be said that building the affected souls is one of the variables, unexpected or surprise is available or remains in the chain of normal shifts.

Results of study matched what came along with Gössling et al (2020) when they argued that the emerging corona virus changed the behavior of the consumer and its interests and largely determined commodities, corrected consumer concepts with its keenness to save and save, as far as possible from random expenses, crisis management, resorting to financial planning and spending, and many daily habits decreased through delivery applications and visiting restaurants. The acquisition of all new electronic devices and smart phones, especially as people suffer mainly from a craze for technology, but the majority have changed their programs and behaviors at the economic and social level.

Building on this new consumer behavior in the world during the Covid-19 pandemic, the study drew a change in consumption habits and its contents in the world that might lead to a change in consumer thought. Also, new consumption patterns may become long-term, that is, to continue in the post-pandemic era. This is consistent with what consumers in some countries refer to as they intend to adopt long-term behavioral changes to continue beyond the current situation which appeared to be rhyming with what Roggeveen and Sethuraman (2020) regarding the change in retailing business during the quarantine and lockdown that results from the spread of the pandemic.

In addition, the study demonstrated that new consumption patterns may affect the supply and demand network. For example, when consumers are accustomed to staying at home depending on online shopping, their lifestyles such as "eating at home" may provide more opportunities for the fresh food and grocery delivery industry. The vegetable and fruit markets, which used to be a major offline mode, may turn into an online mode, such as offering online sales and delivery services which came as according with a study by Penela et al (2010).

\section{Conclusion and Recommendations}

When dangerous indicators begin to appear within societies, they appear dangerous because they threaten the composition of the secure economic fabric, as well as sudden changes in the consumer composition and subjecting many behaviors to accountability and review, there is a very high possibility that touches the realization that many may face questions that they cannot answer, and provides options unaware of its consequences, leaving it without management and control, in light of the spread of the Corona pandemic that has befallen the world.

In fact, the immediate economic impact of the pandemic began to become clear, which contributed to setting a global emergency plan and technology setting goals, disclosing intentions, and activating precautionary and solidarity measures that will protect economies from potential harm and what the world can do about it, but rather about the whole matter.

In this regard, due to the convenience that consumption via the Internet provides while staying at home, and with the generalization and spread of technology and the development of smart phone applications, the digital and electronic aspect of retail business may be strengthened faster than previous expectations worldwide.

Based on the above; current study raises the following questions:

\section{- Will society's behavior change after the pandemic's demise, and will this behavior turn into an economic mind that measures things in numbers?}

There is a need not to forget that the Corona pandemic has a major impact on the political, economic and social path, and this has contributed to educating people, which makes us believe that its mission is only to monitor the change of our consumer habits. 
Based on above results, current study recommends the following:

- Retailers and service providers need to adopt a new strategy based on two basic pillars: providing new and distinct value to the consumer and constantly increasing production capacity.

- Companies need to develop effective marketing strategies and enhance their presence in the e-commerce sector.

- The importance of personalizing the consumer experience to ensure successful results.

- Achieve outstanding value for consumers and enhance its ability to develop a strong e-commerce strategy

\section{References}

Calder, B. J., Isaac, M. S. \& Malthouse, E. C. (2016). How to capture consumer experiences: A context-specific approach to measuring engagement: Predicting consumer behavior across qualitatively different experiences. Journal of Advertising Research, 56(1), 39-52. https://doi.org/10.2501/JAR-2015-028

Campbell, D. \& Frei, F. (2010). Cost structure, customer profitability, and retention implications of self-service distribution channels: Evidence from customer behavior in an online banking channel. Management Science, 56(1), 4-24. https://doi.org/10.1287/mnsc.1090.1066

Claiborne, C. B. \& Sirgy, M. J. (2015). Self-image congruence as a model of consumer attitude formation and behavior: A conceptual review and guide for future research. In Proceedings of the 1990 academy of marketing science (AMS) annual conference (pp. 1-7). Springer, Cham. https://doi.org/10.1007/978-3-319-13254-9_1

Czarniewski, S. (2014). Changes in consumer behavior in the market and the value of companies. European Journal of Research and Reflection in Management Sciences, 2(2).

Dakduk, S., Ter Horst, E., Santalla, Z., Molina, G. \& Malavé, J. (2017). Customer behavior in electronic commerce: a Bayesian approach. Journal of theoretical and applied electronic commerce research, 12(2), 1-20.https://doi.org/10.4067/S0718-18762017000200002

De Mooij, M. (2019). Consumer behavior and culture: Consequences for global marketing and advertising. SAGE Publications Limited.

Echchakoui, S. (2016). Relationship between sales force reputation and customer behavior: Role of experiential value added by sales force. Journal of Retailing and Consumer Services, 28, 54-66. https://doi.org/10.1016/j.jretconser.2015.07.014

Gössling, S., Scott, D. \& Hall, C. M. (2020). Pandemics, tourism and global change: a rapid assessment of COVID-19. Journal of Sustainable Tourism, 1-20. https://doi.org/10.1080/09669582.2020.1758708

Han, J., Ding, H., Qian, C., Xi, W., Wang, Z., Jiang, Z. \& Zhao, J. (2015). Cbid: A customer behavior identification system using passive tags. IEEE/ACM Transactions on Networking, 24(5), 2885-2898. https://doi.org/10.1109/TNET.2015.2501103

Jaakkola, E. \& Alexander, M. (2014). The role of customer engagement behavior in value co-creation: a service $\begin{array}{lllll}\text { system perspective. Journal of service rearch, 17(3), } & \text { 247-261. }\end{array}$ https://doi.org/10.1177/1094670514529187

Jiang, W. \& Chen, X. (2016). Optimal strategies for manufacturer with strategic customer behavior under carbon emissions-sensitive random demand. Industrial Management \& Data Systems. https://doi.org/10.1108/IMDS-08-2015-0321

Juaneda-Ayensa, E., Mosquera, A. \& Sierra Murillo, Y. (2016). Omnichannel customer behavior: key drivers of technology acceptance and use and their effects on purchase intention. Frontiers in psychology, 7, 1117. https://doi.org/10.3389/fpsyg.2016.01117

Jung, J. H. \& Yoo, J. J. (2017). Customer-to-customer interactions on customer citizenship behavior. Service Business, 11(1), 117-139. https://doi.org/10.1007/s11628-016-0304-7 Kannan, P. V., Jain, M. \& Vijayaraghavan, R. (2015). U.S. Patent No. 9,129,290. Washington, DC: U.S. Patent and Trademark Office.

Kumar, A., Bezawada, R., Rishika, R., Janakiraman, R. \& Kannan, P. K. (2016). From social to sale: The effects of firm-generated content in social media on customer behavior. Journal of Marketing, 80(1), 7-25. https://doi.org/10.1509/jm.14.0249

Lantos, G. P. (2015). Consumer behavior in action: Real-life applications for marketing managers. Routledge. 
https://doi.org/10.4324/9781315705439

Lim, W. M. (2015). Antecedents and consequences of e-shopping: an integrated model. Internet Research. https://doi.org/10.1108/IntR-11-2013-0247

Lin, A. J., Li, E. Y. \& Lee, S. Y. (2018). Dysfunctional customer behavior in cross-border e-commerce: A justice-affect-behavior model. Journal of Electronic Commerce Research, 19(1), 36-54.

Lu, X., Li, J. \& Yang, F. (2010). Analyses of location-price game on networks with stochastic customer behavior and its heuristic algorithm. Journal of Systems Science and Complexity, 23(4), 701-714. https://doi.org/10.1007/s11424-010-9058-9

Mathras, D., Cohen, A. B., Mandel, N. \& Mick, D. G. (2016). The effects of religion on consumer behavior: A conceptual framework and research agenda. Journal of Consumer Psychology, 26(2), 298-311. https://doi.org/10.1016/j.jcps.2015.08.001

Moon, H., Park, J. \& Kim, S. (2015). The importance of an innovative product design on customer behavior: development and validation of a scale. Journal of Product Innovation Management, 32(2), 224-232. https://doi.org/10.1111/jpim.12172

Öğüt, H. \& Onur Taş, B. K. (2012). The influence of internet customer reviews on the online sales and prices in hotel industry. The Service Industries Journal, 32(2), 197-214. https://doi.org/10.1080/02642069.2010.529436

Pandža Bajs, I. (2015). Tourist perceived value, relationship to satisfaction, and behavioral intentions: The example of the Croatian tourist destination Dubrovnik. Journal of Travel Research, 54(1), 122-134. https://doi.org/10.1177/0047287513513158

Penela, D., Regueiro-Cueva, A., Ortiz-Pérez, J. T. \& Sitges, M. (2010). Myocarditis due to pandemic influenza A (H1N1). Revista Española de Cardiología (English Edition), 63(11), 1386-1387. https://doi.org/10.1016/S1885-5857(10)70267-X

Roggeveen, A. L. \& Sethuraman, R. (2020). How the COVID Pandemic May Change the World of Retailing. Journal of Retailing, 4(2). https://doi.org/10.1016/j.jretai.2020.04.002

Sekaran, U. \& Bougie, R. (2016). Research methods for business: a skill-building approach (7th ed.). Haddington: John Wiley \& Sons.

Shah, D., Kumar, V. \& Kim, K. H. (2014). Managing customer profits: The power of habits. Journal of Marketing Research, 51(6), 726-741. https://doi.org/10.1509/jmr.13.0423

Singh, P. \& Singh, M. (2015). Fraud detection by monitoring customer behavior and activities. International Journal of Computer Applications, 111(11). https://doi.org/10.5120/19584-1340

Steinhart, Y., Mazursky, D. \& Kamins, M. A. (2013). The process by which product availability triggers purchase. Marketing letters, 24(3), 217-228. https://doi.org/10.1007/s11002-013-9227-4

Sudbury-Riley, L. \& Kohlbacher, F. (2016). Ethically minded consumer behavior: Scale review, development, $\begin{array}{llll}\text { and validation. Journal of Business } & \text { Research, 69(8), }\end{array}$ https://doi.org/10.1016/j.jbusres.2015.11.005

Sweeney, J. C., Danaher, T. S. \& McColl-Kennedy, J. R. (2015). Customer effort in value co-creation activities: Improving quality of life and behavioral intentions of health care customers. Journal of Service Research, 18(3), 318-335. https://doi.org/10.1177/1094670515572128

Tankovic, A. C. \& Benazic, D. (2018). The perception of e-servicescape and its influence on perceived e-shopping value and customer loyalty. Online Information Review. https://doi.org/10.1108/OIR-12-2016-0354

Vazifedoost, H., Ansar, M. \& Yekezare, A. (2013). How customer satisfaction changes behavior: A case study of banking industry. Management Science Letters, 3(6), 1587-1892. https://doi.org/10.5267/j.msl.2013.05.031

Voinea, L. \& Filip, A. (2011). Analyzing the main changes in new consumer buying behavior during economic crisis. International Journal of Economic Practices and Theories, 1(1), 14-19.

Wang, H. (2015). Analysis on the Changes in Consumer Behavior and Marketing Countermeasure. In SHS Web of Conferences (Vol. 17, p. 01007). EDP Sciences. https://doi.org/10.1051/shsconf/20151701007

Yu, Q., Allon, G. \& Bassamboo, A. (2017). How do delay announcements shape customer behavior? An empirical study. Management Science, 63(1), 1-20. 
Zhang, D., Dai, H., Dong, L., Qi, F., Zhang, N., Liu, X. \& Yang, J. (2017). How do price promotions affect customer behavior on retailing platforms? evidence from a large randomized experiment on alibaba. Evidence from a Large Randomized Experiment on Alibaba (August 30, 2017). https://doi.org/10.2139/ssrn.3029707

Zhang, K. Z. \& Benyoucef, M. (2016). Consumer behavior in social commerce: A literature review. Decision Support Systems, 86, 95-108. https://doi.org/10.1016/j.dss.2016.04.001

\section{Copyrights}

Copyright for this article is retained by the author(s), with first publication rights granted to the journal.

This is an open-access article distributed under the terms and conditions of the Creative Commons Attribution license (http://creativecommons.org/licenses/by/3.0/). 